\section{Redes de saúde de trabal hadores e ambiente: uma construção social que responde à Globalização Corporativa Neoliberal}

N etworks for workers' health and environment: a social construct that responds to Corporate $\mathrm{N}$ eoliberal Globalization

\section{H eleno Rodrigues Corrêa Filho 1}

0 artigo de Siqueira, Castro e Araújo - "A globalização dos movimentos sociais: resposta social à Globalização Corporativa N eoliberal" permite analisar os movimentos sociais partindo da perspectiva de que é viável a união das forças progressistas através e além das fronteiras nacionais. Propõe-se construir uma analogia: se o capitalismo corporativo internacional reduziu as forças do poder estatal e subordinou as economias nacionais, o mesmo potencial de expansão pode ser utilizado pelos movimentos sociais que adotam a solidariedade, o crescimento social e a justiça como padrões de desenvolvimento opostos à concentração de renda e aumento da iniqüidade.

A analogia está fundamentada na compreensão que pensadores modernos desenvolveram sobre o que significa a palavra globalização. Como não existe consenso filosófico na literatura abordada, deixa-se aberta para leitores e críticos a possi bilidade de aderir à vertente dos que apontam a imprecisão (Fiori, 1997; M arcuse, 2000), para que dela se utilizem com a intenção de negar a possibilidade para a ação reativa dos movimentos sociais. Aqueles que tomem esta vertente estarão, possivelmente, antepondo formulações teóricas que não geram aproximação da realidade do capitalismo monopolista internacional do início do século 21. Essa abordagem resumiria em si o ceticismo diante da possibilidade do uso da tecnologia da comunicação mais avançada como instrumento de luta social pelas classes subordinadas e seus intelectuais orgânicos. Essa negação encontraria resistência diante dos fatos do consumo estendido de bens de computação doméstica, da circulação universal da informação nas redes e da possibilidade de propor idéias e ações coletivas próximas do ideal anárquico de fins do século 19.

1 Departamento de M edicina Preventiva e Social/FCM D/

Unicamp. helenocf@unicamp.br

Seria possível confundir a negação dessa possibilidade de construção social com a negação do instrumento em si da formação das modernas redes de informática. N egar a possibilidade de que as máquinas da comunicação possibilitem avanços para trabal hadores e ambientalistas seria semelhante à proposta do movimento ludista de destruir as máquinas para libertar o operariado da produção em série.

Outro caminho igualmente difícil e sutil para fundamentar a negação pode, no entanto, estar cheio de verdades tecnológicas incontestáveis como: é possível e já existe, em medida variada, o controle corporativo, a repressão política e mesmo policial da informação que transita na Internet. Inegável também é a submissão da informação livre aos canais de satélite controlados pelas mesmas corporações às quais se pretende contrapor um modelo solidário de comunicação. 0 aumento da informação inútil, o lixo da rede mundial de computadores, também dificulta a atuação do homem comum engajado na busca de elementos transformadores. A seleção da informação válida e da fonte segura também é dificultada pela presença de contra-informação sem validade. A "notícia plantada" circula mais rapidamente como elemento que desmobiliza e confunde. I mportaria reconhecer a afirmativa de intel ectuais da informação de que a Rede M undial de Computadores tem "1 milha de extensão e uma polegada de profundidade".

Todas as condições mencionadas para fundamentar a negação com base tecnológica factual evidenciam que a utilização da rede para informação não se constrói sem grupos humanos que entrem em contato pessoal, façam reuniões periódicas, testem suas realizações e propostas em viagens de intercâmbio e na literatura impressa. Não se pode prescindir de partidos, escolas, organizações e indivíduos em papel de liderança carismática, como afirmam os autores. Nessa vertente, a negação da via globalizadora dos movimentos sociais se enfraquece.

A outra via de interpretação da analogia proposta pelos autores é a conexão dos conceitos de Chomsky (2003), H erman (1999) e Santos (2000) sobre a globalização. N esta vertente, pode-se mesmo compartilhar com Fiori (1997) a idéia de que a imprecisão não impede a utilização do conceito de global ização na forma instrumental. Esta proposição traz consigo a compreensão rápida da crítica bem-humorada ao empregar e explicar o acróstico "Tina", que através do apelido feminino designa a mensa- 
gem de que não existe alternativa para fugir da globalização. Os povos dependentes implantarão o modelo econômico transnacional global sem outra escolha. Evidente que contra essa ameaça se levanta a proposta de mobilização social através das redes.

0 desenvolvimento do argumento sobre a dureza do mundo globalizado, ainda que não definitivamente estabelecida uma definição para o termo, se ben eficia das contribuições de Petras (2000), Amin (2001) e da pensadora brasileira Druck (1999). Com eles é possível retomar as políticas de globalização como fato imperialista, além de reconhecer nos órgãos multilaterais - FMI, Banco M undial, entre outros instrumentos de execução da política neoliberal consensual para a drenagem de recursos que deixam de ser investidos em desenvolvimento social.

A argumentação desenvolvida sobre a degradação humana e ambiental imposta pelo model o imperialista global conduz à proposta da formação das redes sociais com características inovadoras no tecido político moderno. São marcantes as afirmativas sobre as características das redes: policêntricas, flexíveis e difusas, ultrapassando os limites dos estados. As vantagens táticas de inúmeras formas de ação completam a definição do instrumento de crescimento dos enlaces entre pessoas e organizações sem um comitê diretivo com função de representação ou comando.

Esta proposta permite, segundo os autores, agregar diferentes ordens de motivação, desde a política até a religiosa, para a confluência dos valores humanos que negam a dominação imposta pelo modelo globalizado neoliberal. Realiza-se o "nivelamento 'por cima' de direitos humanos, ambientais e sociais".

U m exemplo prático no Brasil é a unificação dos movimentos pela saúde dos trabalhadores e o movimento pelo desenvolvimento sustentável, produção mais limpa e preservação ambiental. As características das redes em nascimento a partir de fins do século 20 se beneficiam diretamente desta proposta. U m fato novo é a real ização de congressos em que representantes populares, sindicais e acadêmicos se reúnem para debater temas de segurança no trabalho, produção e ambiente, tal como ocorreu em Salvador, no ano de 2002.

0 importante nessa analogia é que é possível utilizá-la para dar forma e ação a conceitos que estão compartimentalizados em categorias estanques da análise social e da ação política.
A liberdade de cada componente é a base para que a aglutinação de distintas compreensões não encontre obstáculos para a ação coletiva naquilo que pode resumir seu consenso mínimo. Esse estado de concordância básica permitiria agir segundo regras de sobrevivência que não distinguem na essência os desejos de populações, trabalhadores, ambientalistas e políticos.

Neste ponto, a afirmativa de que está surgindo um novo "super" poder global que crescentemente demonstra sua capacidade e força para propor alternativas de paz, desenvolvimento, e democracia em todo o mundo soa inevitavelmente como nova utopia. Toda utopia existe para ser contestada pelos que pensam sua essência. No entanto, existe para função idílica dos que sonham um mundo novo através dos tempos, e se permitem, através de palavras, expressar o desejo do bem não atingido. À guisa de conclusão sobre as possibilidades deste debate, diríamos que em um mundo carente de utopias e dos que a defendam, não cabe a destruição pelo dogma.

\section{Nota}

Todos os autores citados estão nas referências do artigo comentado.

\section{Globalização dos movimentos sociais: a resposta social à Globalização Corporativa Neoliberal}

Social movement globalization:

the social response to Corporate

Neoliberal Globalization

\section{Guilherme Franco N etto 1}

A tese central do artigo "A globalização dos movimentos sociais: resposta social à Globalização Corporativa N eoliberal", de autoria de Carlos Eduardo Siqueira, Hermano Castro e Tânia Araújo, é que, em resposta aos diversos impactos negativos da Globalização Corporativa $\mathrm{N}$ eoliberal, apresentada como o modelo hegemônico do capitalismo no final do século 20 , os movimentos sociais internacionais têm teci-

\footnotetext{
1 Funasa.

guilherme.netto@funasa.gov.br
} 